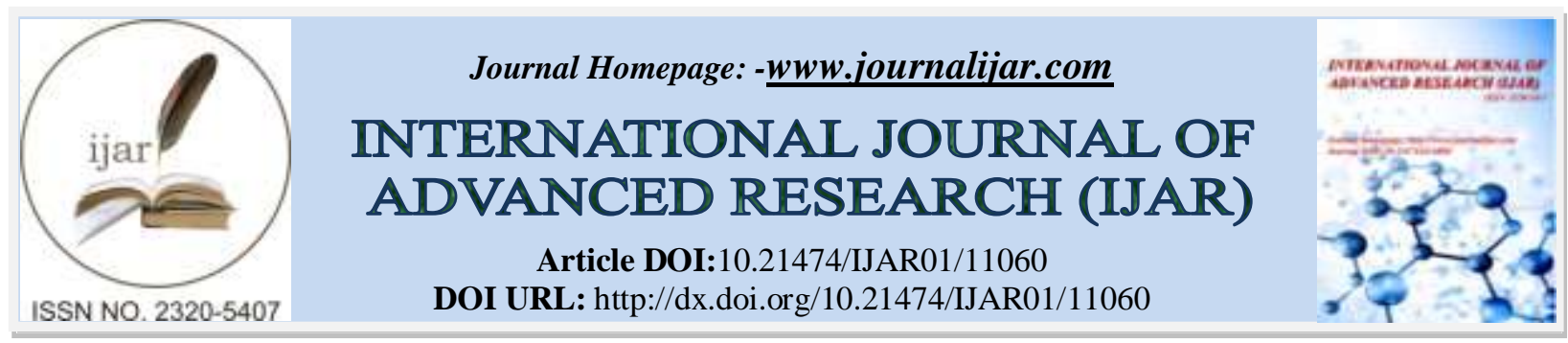

RESEARCH ARTICLE

\title{
CONTEMPORARY ANALYSIS OF ECONOMIC STATUS OF INDIA \& NEED OF SKILL MAPPING
}

\author{
Vishal Varma ${ }^{1}$, Prof. (Dr.) Ravi Goyal ${ }^{2}$, Dr. (Mrs.) Pallavi Agarwal ${ }^{3}$ and Reshu Gupta ${ }^{4}$ \\ 1. PhD Scholar, SES, Bhartiya Skill Development University Jaipur, India. \\ 2. Principal, School of Entrepreneurship Skills, BSDU Jaipur, India. \\ 3. Astt.Prof. School of Entrepreneurship Skills, BSDU Jaipur, India. \\ 4. PhD Scholar, SES, Bhartiya Skill Development University Jaipur, India.
}

\section{Manuscript Info}

\section{Manuscript History}

Received: 01 April 2020

Final Accepted: 05 May 2020

Published: June 2020

\section{Key words:-}

Economic Parameters, Industrial Paradox, Skill Initiative, Livelihood With Skill

\begin{abstract}
The rapid progress India has made in the last couple of years on the economic parameters is extraordinary and enthusiastic. Ease of doing trade or get rid of intensive inspector system, India now have a positive environment for foreign investors, NRIs and other countries.Economic parameters are more concrete than political rules, that is, whose status across the globe increases, its international strength increases automatically. Economic status is not a matter of biased opinion or bizarre conjecture, it is decided on the basis of solid data, facts and figure. India's economic status is steadily increasing, it does not mean that the problems are over. Increasing status simply means that the necessary strength to deal with problems is increasing.In the last decade, with the advent of technology there is a qualitative and radical change occurred in India's economy from agricultural activities to manufacturing and service-oriented activities. Similarly, this also made impact on the employment factors. Skill initiatives going through a difficult situation in INDIA, where the youth of the country stepping into the labour market and are looking for jobs; on the opposite hand, industries are complaining of unavailability of correctly and cuttingedge professional manpower. This paradox reflects the criticality of skill development in context of need identification, to boost the employability of the developing young population and also to gear-up the economic system to understand the target of faster and inclusive increase with innovative ideas.
\end{abstract}

Copy Right, IJAR, 2020,. All rights reserved.

\section{Introduction:-}

Economic Growth: India's All Time Need

There is significant economic news that India has jumped from number 63rd to number 77th in the world list of 'Ease of Doing Business Index'. As a matter of fact, India has jumped 79 places since 2014. In 2014, India was at 142nd position, while in 2018 it has come down to 77th. This in itself is a huge success. It is also successful and bright because all changes do not come easily in a country like India. Almost every major issue has legal ramifications, protests and agitations. It is also successful and bright because all changes do not come easily in a country like India. China is at $31^{\text {st }}$ position and we are looking forward to beat the china in coming years. 
Lot of big questions arise in a democratic system about even small reform. Indian democracy having different mindset with various oppositions, there is media, there are conjugated judicial system. Any reform must pass through the litmus test of these essential elements in the democratic system. Democracy has its own essential mess. China is free from this type of democracy. Liberty from democracy accelerates the implementation of policies in many cases. They can show great speed in implementing whatever is right for the top leaders there. The dictatorship has its own pace which is not possible into a large democracy like India. Yet a jump of 79 places in six years is a huge and remarkable achievement and every element from political leadership to bureaucracy deserves congratulations for this achievement which has made this level possible for ease of doing business.

The aim of this research article is not to criticize Indian democracy, we are proud of our healthy and multi-faceted democracy. This comparison is necessary because almost all intellectuals and data experts evaluate each and every Indian achievement with China, but very cleverly hide the difference between the political systems. We have to keep in mind that political systems are the most important measures of economy and changing world. We have to also remember that China is not having parliamentary democratic system.

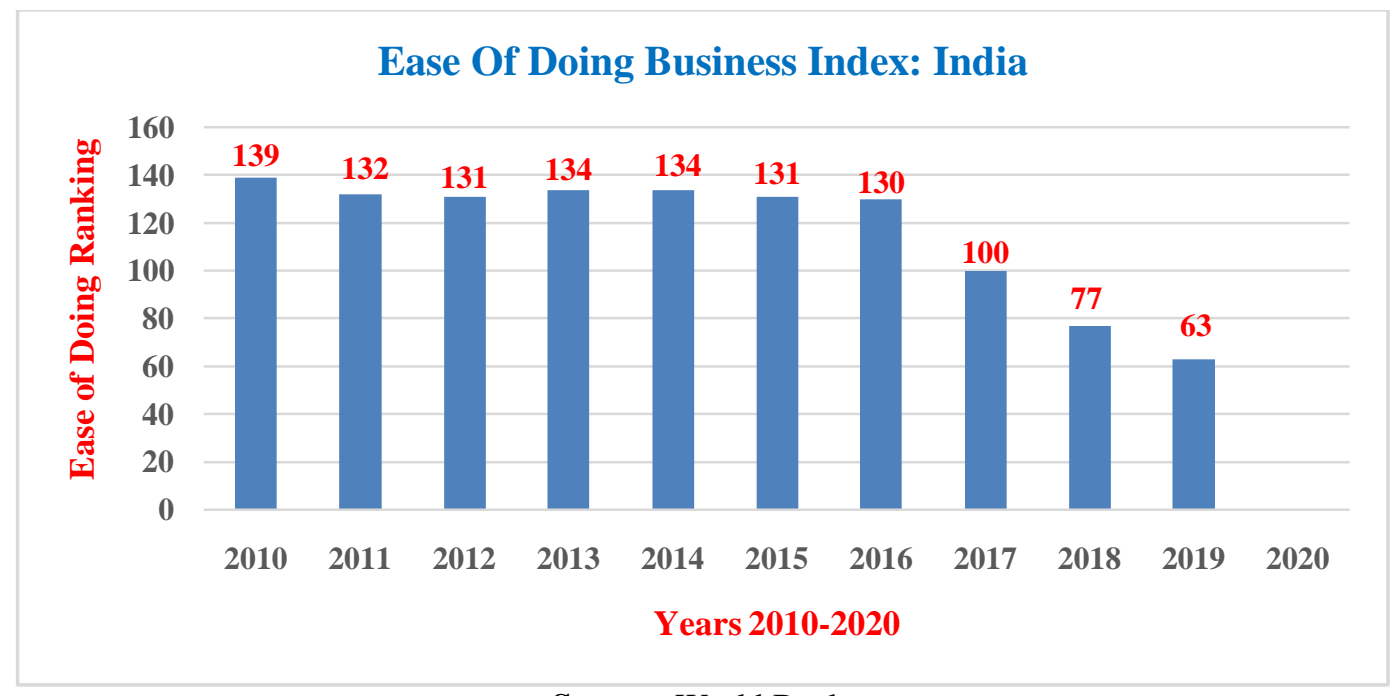

Source: World Bank.

\section{Components Setting Up Economic Growth}

This new business ranking of India can become a great way to woo global investors in the world market. India's top leadership will not back down in spreading it widely, they have great skill to reach all the achievements so far. But some issues still require deep thinking and work.

\section{Notable reasons for concern:}

1. The closure and insolvency of firms are still a challenge for the Indian business.

2. Economic cases drag on for years.

3. Recently some action under insolvency law seems to be taking place at a fast pace. But it is necessary to increase its speed.

4. The pace of property registration in India is yet to gain momentum. It remains to be corruption free.

5. The process of tax reforms is going on, but if it speeds up, it will be easy to go beyond India's 'ranking' fifty in Ease of doing business.

Although this pace is also unprecedented for a large democracy like India, but there is so much work left to do that there is no scope to sit tired. Therefore, the speed at which the reforms have been going on till now, should be further accelerated and the journey should be decided. Next years, India should be in the top fifty and efforts should be made continuously.

\section{Transparency in the economy}

It has been almost four years since the announcement of demonetisation. As we all witnessed. DeMo was a major breakthrough step to hit corruption. A lot has been changed in the economy after DeMo. 
Names like Paytm, Yono by SBI, Mobikwik and other digital wallets are now familiar. Paytm has around 300 million users. That is, about one-fourth of the population of this country is a user of Paytm. Paytm's user numbers are approximately equal to the population of the United States. The Paytm brand is now using other reach. Its mobile app 'Paytm Money' is working for direct investment in mutual funds.

\section{Digital payment}

If all digital transactions of money are accounted for, then since demonetisation, online transactions have increased by 440 percent so far. The more the economy goes online, the better it is in terms of transparency.

\section{Increased Taxpayers}

According to the figures, between 2014-2015 to 2017-18, the number of individual taxpayers showing income of more than Rs 1 crore per annum has increased by about 68 percent in about four years. According to the data, the number of such millionaire taxpayers was 48,416 in 2014-15, which increased to 81,344 in 2017-18.

It can be rejoiced that there was an increase in taxpayers of about 68 percent in just four years. There was a total of 4 crore 72 lakh taxpayers in 2012-13, this increased to 6 crore 26 lakhs in 2016-17. Undisclosed income of Rs 5,400 crore came into action after demonetisation. In 2016-17, about 90 lakh new taxpayers were added to the tax system. This is an increase of about 80 percent compared to the number of taxpayers who usually grow every year. All this happened due to demonetisation because there was concern in the minds of the people that the government may take some drastic steps. Therefore, the tax base of the government has broadened. Overall, demonetisation proved to be such a shot that brought some positive results despite not being targeted. One positive result of this was, that people were oriented towards cashless economy. There are many benefits of a cash-less economy, The new creation of black money stops to a certain extent.

\section{India as International Economic Giant: Concern for Orthodox Masters}

People know that a source of strength lies in economic strength. The strengthening of Indian brands somewhere bothers those forces, who want to see themselves stronger than India. Everyone has the right to strengthen himself, but there is a lot of conflict of interest in areas where some brands have not been challenged for years. In such a situation, those selected brands perceive their status, their strength as eternal, and where they face challenges, they make every effort to challenge the rival Indian brands by hook or by crook.

A brand from India RuPay card is offering challenge, to a multinational brand such as MasterCard. There are around four crore credit cards in India and about 98 crore debit cards, about half of which are under the Indian RuPay card system. This thing hurts all foreign card services including MasterCard. For years, only foreign brands like Visa, MasterCard have been making inroads in this area. America's master card company has complained to the American government that the RuPay card is being extended in the name of India's nationalism. The intention of the master card company is that the US government should stop present Indian government from doing so in the name of his nationalism. The thing to understand is that when it is time to expand the business, all the multinationals talk about globalization and say that the whole world is one, but remember when their earnings are hurt due to some logical regional reasons suddenly, they cry foul and start playing victim card.

America is a powerful country in the world, but that strength should not be used to eliminate rival brands of American companies. The thing to understand is that in the business world nationalism can be used to an extent, any company has to provide cheaper and better services to survive in the market. Customers' of multinational Vodafone company cannot be induced to use the services of government owned BSNL or MTNL in the name of nationalism. So American company or any foreign company should make their products cheaper and better instead of complaining to their respectivegovernments.

The Indian consumer tends towards cheap products, it does not matter whether they are native or foreign. More than fifty percent of India's smart phone market is occupied by Chinese brands. It is a different matter that now about 94 percent of the total mobiles sold in India are being made in India. Many of those brands may be Chinese, but they are being manufactured in India. Indians are moving towards cheap Chinese phones. In the essence, there is a limited role of nationalism or patriotism in the market. Any brand can last only on the basis of its capabilities, durability and cost effectiveness. Therefore, all foreign brands including MasterCard should make their services affordable and better. Be it an Indian brand or a foreign brand, they have to build their capabilities to survive in the 
market for a long time. There is no doubt that the Indian economy is continuously growing and has made its name among the world's largest and efficient economies.

\section{India's growing economic status in the world}

India announced a one-billion-dollar loan to Russia. Children growing up in the seventies and eighties have read a lot of news that Russia helped India in this way. But India is such in an economic position to help Russia, this is a new thing.

India announced a loan of $\$ 1$ billion for the development of Russia's resource-rich Eastern Region (Far East Region). Prime Minister Narendra Modi recently visited Russia in September 2019. The debt given by India to foreign countries has increased more than two and a half times in previous years. India lent $\$ 11$ billion to foreign countries in 2013-14, which increased to $\$ 28$ billion in the last financial year 2018-19.

However, India owes most of its debt to countries in Asia, Africa and Latin America which are economically weaker than Russia. The declaration of this level of support to Russia introduces a whole new dimension, especially in the global economy and global politics. In other words, it also underlines a new overall status of India.

Russia's economy has been facing difficulties since 2014. The international sanctions imposed by Russia's occupation of Crimea and the fall in crude oil prices five years ago have caused enormous problems for Russia. In the recession-hit Russian economy, Russian workers' incomes plummeted and taxes increased. It is not uncharacteristic that Russia stood with India with such vigour and aggression on the issue of Kashmir and Article 370 and the whole world understood the warmth of the relationship between Russia and India.

\section{Effect of debt and help}

A major reason behind the impact of China has made in the whole world is that it has distributed loans and especially easy loans to all the countries at a blistering pace. It is not necessary to be an economist to find out the reason behind it. Any country who takes a loan from you, does not usually take any step or voice against you.

It can be considered, that the country needs help from India will take full care of Indian interests. In the Maldives, the help given to India was increased as soon as the government changed. Broadly lending is part of global politics, even if it is related to economics.

Recently African countries - Zambia, Rwanda and Ghana have proposed to India to take copper and gold, and make roads, railways, etc. India has sufficient capabilities to successfully execute such projects. So, in the future, such capabilities of India and India's economic capabilities will give India a new place in the world.

\section{India: Fifth Largest Economy in the World}

India has now become the fifth largest economy in the world with a GDP of \$2.94 trillion. The Indian economy has surpassed Britain and France in 2019. This information is given by a report by the Research Institute of the World Population Review of America. The Institute has stated in its report that India has moved ahead with the earlier policy of becoming self-reliant and is developing as an open market economy. Explain here that the economy of Britain is $\$ 2830$ billion, while the size of the economy of France is \$2710 billion. India's GDP is \$ 10,510 billion based on purchasing power parity (PPP).

\#PPP: "purchasing power parity" comes from the idea that, with the right exchange rate, consumers in every location/country will have the same purchasing power. (Source:Wikipedia) 


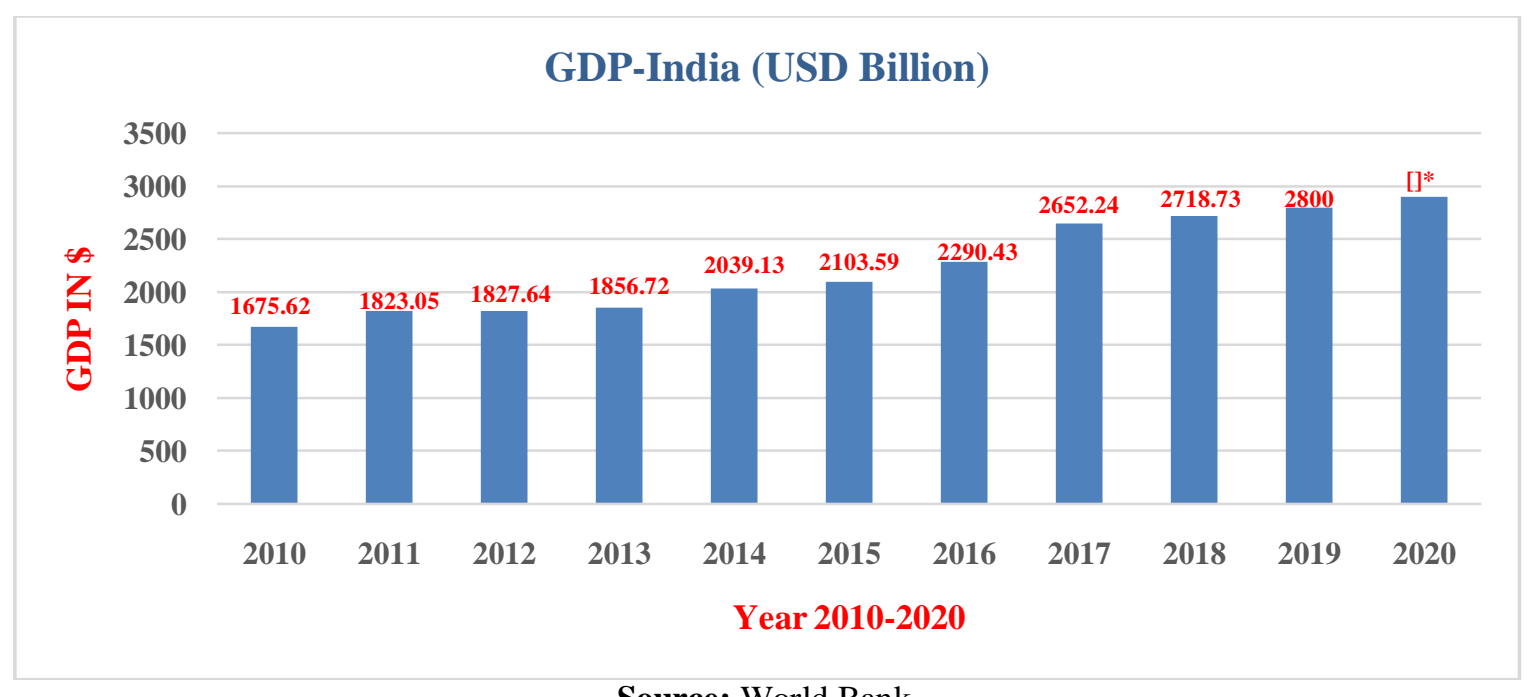

Source: World Bank.

\section{Economic Growth and Jobs Paradigm}

After 2014, micro-small and medium enterprises - a total of 1 crore 35 lakh to 1 crore 49 lakh jobs in MSME sector has been created every year.

How many people have got employment in the new government is an important query which is being asked continuously and repeatedly from couple of years. In a large country like India, if we talk about statistics, there is no such medium, so that we can know exactly how many people are getting employment every year. But there are some standards through which we can formulate an approximate picture of employment seekers in India.

For example, a survey was conducted among more than one lakh micro, small and medium enterprises (MSME) firms. The survey covered 105,347 firms from 305 industrial centres in 28 states. The survey conducted by CII in the MSME sector showed a slight increase in employment of 13.9\% in the last four years or 3.3\% per year, it is little bit relieving in the field of employment generation, due to lack of adequate jobs in the country.

The survey conducted by the Confederation of Indian Industry (CII), said that since 2014, micro-small and medium enterprises - a total of 1 crore 35 lakh to 1 crore 49 lakh jobs in the MSME sector, have been created every year. According to the Labour Bureau the total number of people employed in this sector is 45 crores.

The top job-generating sectors within India include hospitals, hotels, hospitality and tourism, followed by employment generation in the textile and apparel and metal products sectors. Then there were a large number of employment opportunities in the machinery parts, transport and logistics sectors.

For enterprises in which more than 20 employees work, it is mandatory for them to register employees in Employee Provident Fund - EPF. From September 2017 to November 2018, 73 lakh new names were added to it. During the same period, there were 9.2 lakh new registrations in the National Pension Scheme - NPS. Thus, more than 82 lakh people in the country got formal employment.

Apart from this, some independent studies were also done. One such study linked chartered accountant graduate students in 2016-17. According to the study, 17,000 chartered accountants graduated in the year 2016-17. More than 5000 of these students started their own company just after graduation. Now, if a company also provided employment to 25 people, then this number was one lakh twenty-five thousand. Similarly, if we calculate the employment creation under lawyers, professors, doctors, engineers and laborers working under MGNREGA, railways, road-building, construction etc., then this number will also reach in lakhs.

The employment generation program of the Prime Minister-PMEGP, Pradhan MantriRojgarProtsahan YojnaPMRPY, DeenDayal Upadhyaya Grameen KaushalyaYojna-DDU-GKY, Pradhan Mantri Kaushal Vikas YojanaPMKVY and Pradhan Mantri Awas Yojana has provided employment to about 10 lakh people. 
According to a study by the National Council of Applied Economic Research - NCAER, when one lakh rupees is invested in the building construction sector, there is employment generation for 2.69 persons. 6000 crores were spent on the construction sector in 2017-18. In this way employment was arranged for about 40 lakh people with an investment of 60,000 crores. This article was not written to advocate these efforts as an achievement. Each of our next day inspire us to take it one step ahead of the previous day. Let us be dynamic with this aim.

\section{India Facing Economic Slow Down: Facts Vs Myth}

In fact, instead of recession in India, the perception of recession is spreading more. Recession is an intimidating term; it is being done under a thoughtful strategy.

Together, there has been so much news on the sudden economic recession that the common man is confused what will happen now? But has the Indian economy really fallen into recession?

In fact, in the automobile sector, sales have been declining for the last 9 quarters. The textile sector also advertised a decline of about 34 percent. The decline in real estate started from the year 2011, it has not been sustained till date (Although there are many other reasons for the decline in real estate.) In addition, couple of months ago the decline in sales of Parle-G Biscuits also supported the perception of recession. After this, when the figures of the fall in GDP growth for the September 2019 quarter came out, people called it a recession.

The point is to understand the terminology of the economy. There are four conditions in the economy - Boom, Recession, Slowdown and Revival. Apart from this, there is a situation called Depression (Great Recession). There is a need to understand Slowdown, Recession and Depression.

Economic slowdown is a situation when the growth rate is falling below the earlier growth rate. That is, development is happening but its pace has decreased. Let us understand this, every week, a shop gets 7 new customers in addition to old customers. But now 6 new customers are coming in addition to the old customers. It is called slowdown.

In the event of an economic recession, the growth rate becomes negative. Same as above, new customers are not coming to that shop and old customers are also decreasing. If this happens in two consecutive periods (two consecutive quarters in terms of economy), then that shop will be called in recession and when this negative growth rate goes on for many years, it is called depression which was seen in India around 1930.

It is clearly evident that the Indian economy is not in a recession, but in a phase of economic slowdown. This is also confirmed by Morgan Stanley, a global investment and banking specialist. Morgan Stanley, in its report released in August 2019, has expressed fears that global economies may fall into recession in the next 9 months. For this, they consider the trade war between the US and China as the reason.

Other indicators such as the bond-yield curve also appear to be reaching the same level as the 2008 recession. However, Morgan Stanley believes that India is not on the verge of recession but is going through a Crippling slowdown.

Dr. Bimal Jalan, a well-known economist of the country and former Governor of Reserve Bank of India, considers this reduction in demand as economic slowdown and says that this slowdown is cyclical and not structural. Dr. Jalan also states that economic slowdown is limited to just a few sectors and not the entire economy.

According to Dr. Jalan, global economic slowdown will not be a hindrance for India to achieve growth rate of 7.5-8 percent because all factors of production like investment, savings, land and technology are in our favour. Dr. Jalan hoped that it would take one or two years to get out of this slowness.In fact, instead of recession in India, the perception of recession is spreading more. Recession is a scary word. Recession brings inflation, unemployment and poverty.

Recession's Algorithm can be understood when chain reaction occurs at the onset of this assumption. Both entrepreneurs and customers become cautious when this perception begins. The entrepreneur stops investing to avoid the imaginary hassles that may come up in his enterprise, cutting costs which results in retrenchment of employees. This retrenchment reduces the public's spending power. The customer also becomes cautious and postpones the purchase of other items along with storing basic items. 
This reduces the demand for products. Which reduces the production of the company and it speed up the process of retrenchment. This may be called scientific recession. But this psychological slowdown also hurts the economy.

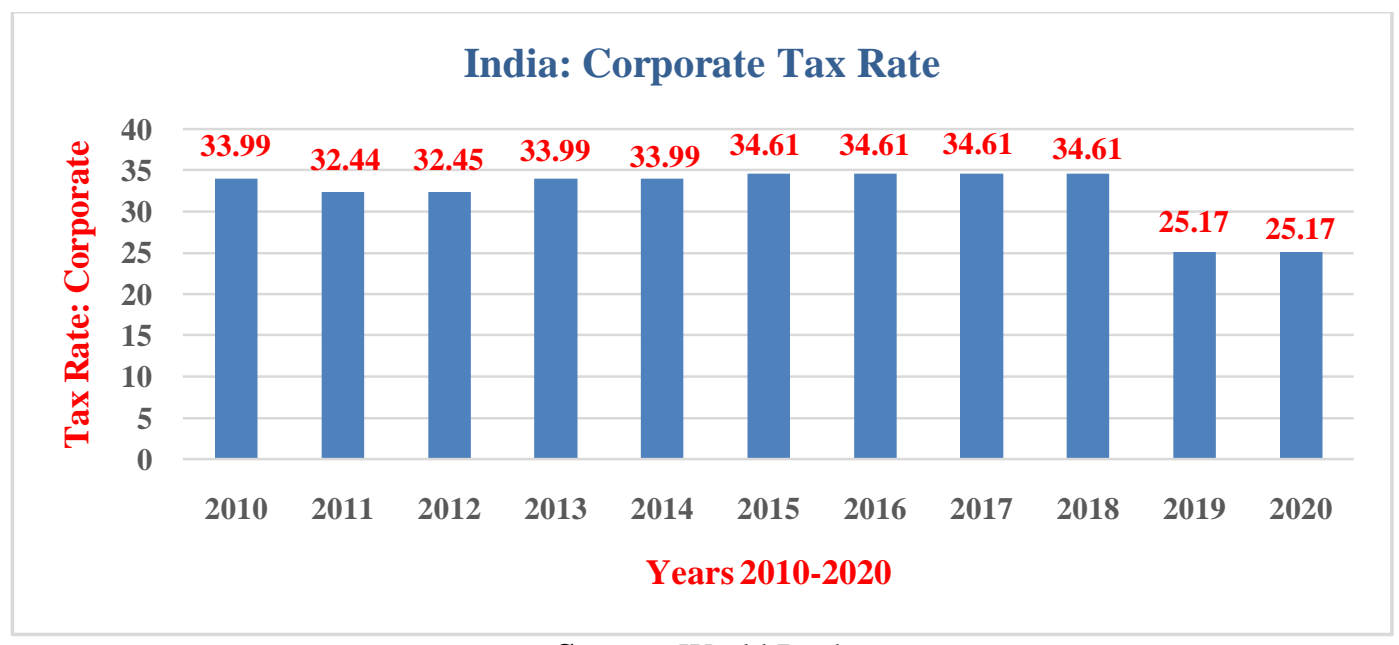

Source: World Bank

\section{Low Jobs: Deficiency of Contemporary Skills(Need of Skill Mapping)}

Unemployment is the major challenge of central and state governments. In this context, most experts argue that the main purpose of education is to get employment, which is also true. If we evaluate the success of education on the basis of employment, then in the context of India, these figures are very distressful. India's unemployment was 3.5 percent in the financial year 2018-19 and unfortunately the situation was same in 2016-17.

According to the above analysis, 1.89 crore people will be unemployed in India in 2019-20, which was 1.86 crores in 2018-19. It is worth mentioning that these figures are of separate financial years, if the cumulative numbers of previous years are added to them. Then the number will become very large and troublesome.

A major reason for this is the magnanimous number of educational institutions that came into existence in uncontrolled numbers from last couple of years. In the name of these educational institutions, education is being conducted indiscriminately. That is why despite the large number of higher educational institutions in India, the quality of education is not contemporary. As a result, it is highly competitive to get admission in premier quality institutes like IITs and IIMs as they naturally do not compromise the student-teacher ratio. Due to tough competition, only fathom students are able to get admission and the quality education of such institute is not adversely affected. During the last 20 years period, the number of private higher educational institutions has increased drastically and the students deprived of admission to IIT and IIM have become an easy choice to get admission into such self-financed institutions.

In the 90 s, the number of higher educational institutions were very limited, so it was very difficult to get admission in such institutes, but in the beginning of the next decade of 90's the situation reversed. Along with giving legitimacy to more educational institutions than necessary, such institutions became abundant. Initially students and parents found it a very attractive proposition, because there was admission without competitive examinations. But by the last years of the decade, not only did the situation change but the number of unemployed youths started increasing steadily. As a result, lakhs of degree holder youth were coming for jobs, but their qualifications lacked quality and skills.

Therefore, it became extremely difficult for such unskilled youth to get jobs in competitive market. Although large number of self-financing educational institutions have catered to the growing demand of students and lack of infrastructure, but most such institutions have forgotten the basic principle of demand and supply, the loss of which is now reflected in the situation of such quality fewer engineering institutes is very worrisome. Most of them have either closed down or are struggling with their existential crisis.

Youngsters with degrees from such engineering institutes are either unemployed or employed in non-technical fields as teachers, bank clerks or in any other way. The question is, when the job was to be done in non-technical field itself, what was the need to get technical education? Some of among these promising graduates are also selected in 
the Union and the State Public Service Commissions, but not all are so talented and fortunate. It is an unfortunate irony that most of the youth are not competitive and skilled enough to get a job.

Is it not a challenge for academicians, administrators, research scholars and governments to think deeply and come up with valuable conclusions?

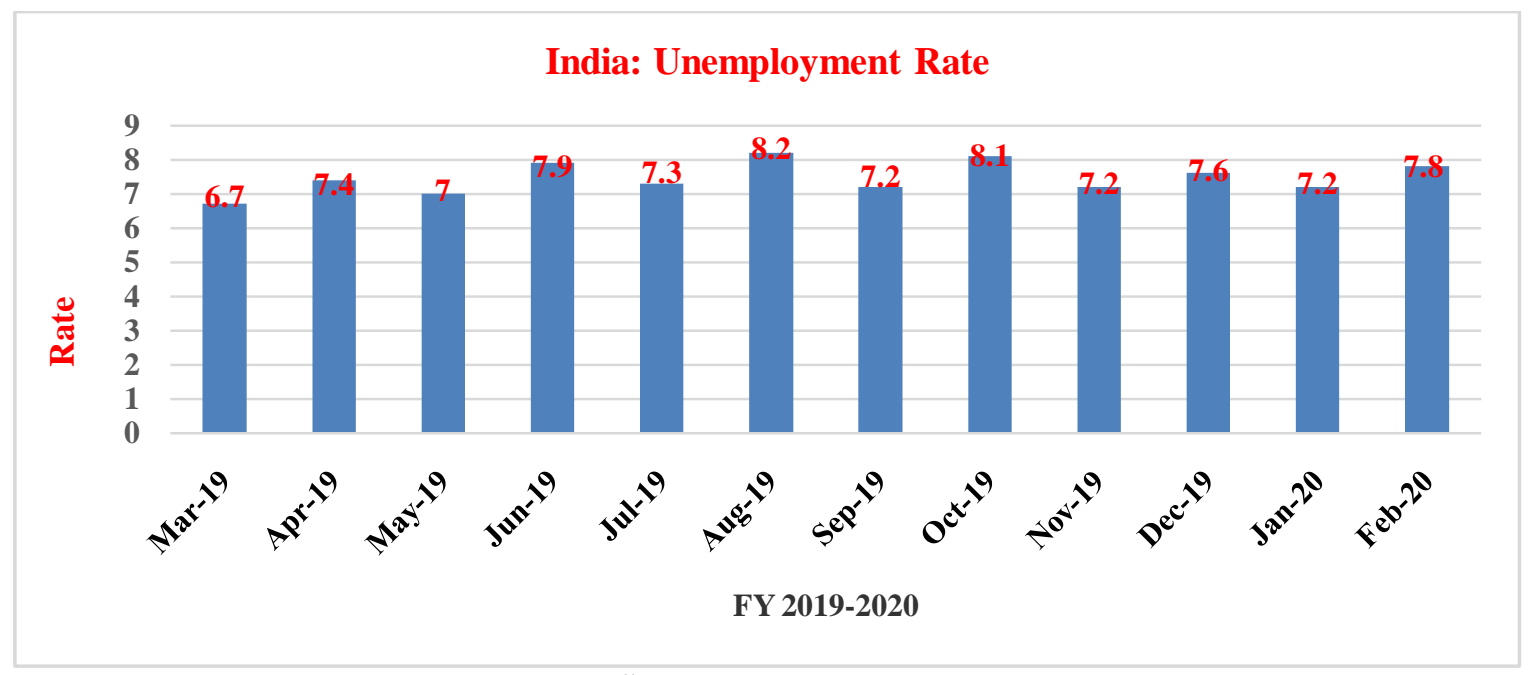

Source: World Bank.

Lack of quality and skilling in education is the biggest reason for this unemployment. Also, the biggest challenge before the system is how to build the basic infrastructure of education according to market demand? In the context of India, contemporary vocational education is the only one, that can make students efficient for the present and future competition and challenges.

Currently many courses of government universities are not suitable for future prospects and job creation, you can guess how relevant the mammoth number of students coming out of the subjects like Sociology, History, Arts and Humanities at graduation and post-graduation level?

The purpose of the article is not to criticize any particular educational subject, but it is a fact that even after achieving mastery in such subjects, the possibilities of employment are extremely limited. Most such students lack technical qualifications, which makes it rare for employers to provide jobs, especially in the private, corporate and manufacturing sector. These types of educational subjects should be modified according to time, market and employment demand. It should be remembered here that, if a large number of students of such inconsistent subjects come out of universities, then the chain reaction and cumulative data of unemployment will never end!!

This situation is also serious for India because in the last seven decades, contemporary vocational education has never been a national priority. Beneficial employment and sustainable livelihoods are India's foremost challenge. Along with this, employment paradigms should also be developed.

Since, India has distinct advantage today over its competitor's in terms of working population below the age of 25 , as we recognized having world's youngest population of working cohort.it is even be noted that alongside of this unique factor India also will have a phase of sharp slowdown in population in next twenty years. This also has been found out within the economic survey of India 2018-19. this means that while the country as a full, will enjoy the "demographic dividend" phase, it'll also witness the transition to 'an ageing society by 2030 '.

The big and foremost challenge today therefore is to convert this "modulation into the dividend" i.e. the quantity of these gainfully contributing the economic process equalling the quantity of these who passionate about them.

\section{Resulting Remarks:-}

According to a study conducted by the Centre for Sustainable Employment of Azim Premji University, it is extremely difficult for undergraduate and postgraduate youth to get jobs. The unemployed people involved in the 
survey said that they do not get employment matching their skills and education. In 2015, about 23 lakh youth applied for 400 vacancies in Category-4 in Uttar Pradesh, of which around one lakh was graduates and postgraduates.

In such youth who are deprived of skill education, the pressure to get a government job can be understood. This demand needs to be fulfilled by the private sector. Also, some of these unemployed youth who are socially and economically capable, can afford to remain unemployed. But for such youth, who have inequality in the dimensions of demography and family income, employment is the only means of livelihood for them.

Education and skill development should follow this 3-tier architecture for reducing unemployment and enhancing sustainable livelihood to foster economic growth:

(a) Education for all, expansion of upper education and specific professional courses viz. architecture, law, medical/paramedical, engineering et al.

(b) Skill development for entry level jobs for those in education, engaged, out of education/dropouts.

(c) ADD Skilling i.e. Up skilling. people who are educated \& have worked or are working or people who are worked and out of job to fulfil the skill requirement for brand spanking new job or aspirants of changed job.

In the present perspective- skill, vocational and technical education can reduce unemployment appropriately in a short time. Vocational courses in skill development can be very effective for this purpose. India needs a large number of educational institutions for quality vocational training. It is an important fact that the government has started working in this direction. In the coming decade, skilful youth will transform the international image of India through jobs and self-employment.

NOTE: All the above figures are as of March 31, 2020. The Corona Pandemic and consecutive lockdowns will have an impact on the upcoming two quarters and the financial year. Therefore, the next study will be conducted on the potential GDP and economic growth rates according to all these concurrent circumstances.

\section{References:-}

1. National Skill Development Corporation, INDIA

2. Ministry of Skill, Entrepreneurship \& Employment, INDIA

3. Ministry of Economic Affairs, Government of INDIA.

\section{Webliography:-}

1. https://economictimes.indiatimes.com/

2. https://www.managementstudyguide.com/

3. https://www.india.gov.in/

4. https://dipp.gov.in/

5. https://dea.gov.in/

6. https://mhrd.gov.in/higher_education

7. https://data.worldbank.org/. 